\title{
Effect of Avocado pulp extract on chlorpyrifos-induced thyroid gland injury in rats: A histological and morphometric study
}

\author{
Original \\ Article \\ Amira A Kassab ${ }^{1}$ and Mona El-Aasr ${ }^{2}$ \\ ${ }^{1}$ Department of Histology, Faculty of Medicine, ${ }^{2}$ Department of Pharmacognosy, Faculty of \\ Pharmacy, Tanta University, Tanta, Egypt
}

\begin{abstract}
Introduction: Chlorpyrifos is a broad-spectrum insecticide with widespread usage in agricultural fields despite its toxic effects on human health. Avocado is a highly valuable fruit proven to have curative and preventive role in numerous diseases. Aim: To evaluate the protective role of avocado pulp extract on chlorpyrifos-induced injury on the thyroid gland in rats.

Materials and Methods: Forty adult male albino rats were divided into four equal groups; control group, avocadotreated group $(300 \mathrm{mg} / \mathrm{kg})$, chlorpyrifos-treated group $(5.4 \mathrm{mg} / \mathrm{kg})$, and both avocado- and chlorpyrifos-treated group. Doses were given orally, daily for 4 consecutive weeks. Specimens of the thyroid gland were processed for histological and immunohistochemical examinations. A morphometric study and statistical analysis of the findings were performed for different groups.

Results: Compared to the control group, the specimens of the chlorpyrifos-treated rats showed degenerated follicles with exfoliated follicular cells in the lumen. Increased amount of collagen fibers and decreased PAS-reaction were observed. Immunohistochemistry showed a significant increase in caspase-3 immunoexpression. The mean height of the thyroid follicular epithelial cells was significantly decreased with significant decrease in area of colloid. In contrast, minimal changes appeared in the group treated concomitantly with both avocado and chlorpyrifos.

Conclusion: Avocado pulp extract exerted an excellent role in protecting the thyroid gland from chlorpyrifos injurious-effects in rats.
\end{abstract}

Received: 31 May 2017, Accepted: 04 December 2018

Key Words: Avocado, chlorpyrifos, thyroid gland.

Corresponding Author: Amira A. Kassab, M.D., Department of Histology, Faculty of Medicine, Tanta University, Tanta, Egypt, Tel.: 00201016697635, E-mail: Amirakassab80@yahoo.com

ISSN: 1110-0559, Vol. 41, No.1

\section{INTRODUCTION}

Worldwide, humans are exposed to many chemicals and environmental contaminants. Among these, chlorpyrifos (an organophosphate insecticide) is extensively used in agricultural and industrial fields as well as domestic purposes. It has broad spectrum activities in controlling many insect pests as well as mites. In many biological systems, chlorpyrifos is known to produce oxidative stress ${ }^{[1,2]}$. So, these agents are not only toxic to pests but also to humans ${ }^{[3]}$. Chlorpyrifos has induced pathological effects on liver, testis, kidney, brain and lung in rats ${ }^{[4-8]}$ as well as in humans ${ }^{[9]}$. It is also described as an endocrine disruptor. It causes significant reduction in testosterone biosynthesis, steroidogenic enzymes and their regulatory proteins expression ${ }^{[10]}$.

Thyroid gland and its hormones have essential biological functions in children as well as adults. They possess essential role in growth and development especially for brain. In adults, the gland hormones are involved in the regulation of protein, carbohydrates and lipid metabolic processes. Moreover, they are essential in regulating heart rate, reproductive functions, emotional steadiness and gastrointestinal functions ${ }^{[1,2]}$. Furthermore, chlorpyrifos significantly affects the thyroid hormones serum concentrations in $\operatorname{rats}^{[12,13]}$.

Generally, organophosphate insecticides are known to cause oxidative damage in animals and humans. Reactive oxygen species production (ROS) and accumulation of oxidative damage are usually involved in the pathophysiology of most diseases caused by these toxic chemicals $^{[14]}$.

Nowadays, natural products play an effective protective role with the clinical therapeutic regimens. Fruits as well as vegetables consumption is associated with decreased risk of many common diseases in human. This is due to high phyto-nutrients that have many health benefits. Avocado, known as "Persea americana", is a greenish pear shaped fruit of firm butter consistency. It is characterized by its high nutritional value, whereas it was considered a high source for proteins, unsaturated fats, iron, potassium, 
phosphorus, and many vitamins as $\mathrm{C}$ and $\mathrm{E}$. Consumption of significant amounts of this fruit results in reduced risks of the cardiovascular diseases as well as regulation of blood clotting time attributed to its high vitamin K. Moreover, it has many benefits in psoriasis, scleroderma, obesity and cancer $^{[15,16]}$.

Previous researchers assumed that avocado helps in controlling the blood cholesterol, liver metabolism and diabetes. In addition, avocado improves the antioxidant defense system because of its high content of the antioxidants flavonoids and phenolic compounds ${ }^{[17]}$. So, this current work was designed to assess the possible protective role of avocado pulp extract on chlorpyrifosinduced thyroid gland injury in adult male albino rats.

\section{MATERIALS AND METHODS}

\section{Material}

1- Chlorpyrifos was purchased from El-Gomhouria Company for Trading Chemicals and Medical Appliances.

2- Avocado pulp extract: Fresh avocado fruits were purchased from local market in Tanta city, Egypt. The fruit extract was prepared at Faculty of Pharmacy, Tanta University. The pulp of the fruits was used to obtain the extract after peeling and removal of their seeds. The pulp was cut into pieces, dried in an oven at $50{ }^{\circ} \mathrm{C}$, and then ground. The extraction was done by maceration process using ethanol $(95 \%)$ at the room temperature. Under reduced pressure, the obtained extract was concentrated by using rotary evaporator. Finally, a solid crude extract was available which constituted about $8 \%$ of the fruit ${ }^{[18]}$.

3- Rabbit polyclonal anti-rat activated caspase-3 antibody ab2302, an apoptotic marker, Abcam, Cambridge, Massachusetts, USA.

\section{Experimental rats}

Upon approval of the study protocol by the local ethical committee, a total of 40 adult male albino rats (225-250 grams) were divided into four equal groups:

Group I (control group) was subdivided into two equal subgroups: subgroup IA received no treatment and subgroup IB received $2 \mathrm{ml}$ corn oil orally once daily for four successive weeks, a solvent for chlorpyrifos.

Group II (avocado-treated group) received avocado pulp extract $300 \mathrm{mg} / \mathrm{kg} /$ day orally dissolved in distilled water for four successive weeks ${ }^{[19]}$

Group III (chlorpyrifos-treated group) received chlorpyrifos $(5.4 \mathrm{mg} / \mathrm{kg} /$ day $)$ dissolved in $2 \mathrm{ml}$ corn oil once orally for four successive weeks ${ }^{[20]}$.

Group IV (avocado- and chlorpyrifos- treated group) received avocado pulp extract and chlopyrifos concomitantly at the same doses and duration as the aforementioned in group II and III.
After the last dose, the experimental rats were anesthetized using sodium pentobarbital $(50 \mathrm{mg} / \mathrm{kg}$, intraperitoneal injection $)^{[21]}$. The skin of the neck was incised and the trachea was exposed and dissected out. The thyroid gland was removed, preserved in the fixative, and then processed for light microscopic examination.

\section{The histological study}

Samples of the thyroid gland were fixed for 24 hours in $10 \%$ neutral-buffered formalin, processed by using routine protocols, put in flat molds and then embedded in paraffin. Finally, $5 \mu \mathrm{m}$ sections were stained with hematoxylin and eosin (H\&E), periodic acid Schiff (PAS) reaction as well as Mallory's trichrome stain ${ }^{[22,23]}$.

\section{Immunohistochemical study}

Ultrathin sections of $5 \mu \mathrm{m}$ thickness were obtained from the formalin fixed, paraffin embedded specimens, and incubated with the primary antibody (activated caspase-3 antibody) in a humid chamber overnight. Thereafter, these sections were incubated with the corresponding biotinylated peroxidase conjugated secondary antibody for one hour. 3, 3'diaminobenzidine (DAB) was used as a chromogen to localize the site of immunoreaction. The immunostained sections were counterstained by adding Mayer's haematoxylin. For negative control sections, the primary antibody was not used ${ }^{[24]}$.

\section{Morphometric study}

The image analysis system (Leica Q 500 MC program) at the Faculty of Medicine, Tanta University, was used to measure:

1- The height of the follicular epithelium in H\&E-stained slides.

2- The area percentage of collagen fibers in Mallory's trichrome stained-slides.

3- The area percentage of colloid in PAS-stained slides.

4- The color intensity of caspase-3 positive immunoreaction.

Five different microscopic fields from each specimen in every study group were examined for the above mentioned parameters at magnification of X400.

\section{Statistical analysis}

One-way analysis of variance (ANOVA) followed by Tukey's procedure were used for data analysis and to compare between the different groups using statistical package for social sciences statistical analysis software (version 11.5; SPSS Inc., Chicago, Illinois, USA). Mean \pm standard deviation were calculated. Probability values $(P)$ of $>0.05$ and $<0.05$ were regarded nonsignificant and significant respectively.

\section{RESULTS}

In the control and avocado-treated groups, H\&E stained sections showed the normal histological structure of the rat thyroid gland. The gland was divided into numerous 
irregular lobules by thin incomplete connective tissue (CT) septa that convey the blood vessels. The lobules consisted mainly of variable sized oval or rounded follicles with capillary beds and connective tissue in between (Fig. 1). These follicles appeared lined with a single cuboidal epithelial cell layer (follicular cells) having central and rounded pale nuclei. Lumina of these follicles were filled with homogenous acidophilic colloid (Fig. 2).

Regarding Mallory's trichrome-stained sections, thin collagen fibers were found separating the gland lobules and also in between the follicles (Fig. 3). Moderate PAS reaction appeared in the basal lamina of these follicles while colloid exhibited marked PAS reaction (Fig. 4).

Concerning activated caspase-3 immunoreaction, weak positive reaction appeared in the nuclei and/or the cytoplasm of few follicular cells (Fig. 5).

In the chlorpyrifos-treated group, H\&E stained sections showed disturbed normal architecture of the thyroid follicles. Many follicles with vacuolated or no colloid appeared in most sections. Disturbed follicular basal lamina and fusion of some follicles were also noticed. Other follicles were dilated with stagnant secretion and flattened nuclei (Figs. 6 and 7). The follicular cells appeared with cytoplasmic vacuoles and deeply stained nuclei (Fig. 8). Other sections showed degenerated follicles with exfoliated follicular cells in their lumens (Fig. 9). Dilated and congested blood capillaries as well as mononuclear cellular infiltration were also seen in between the follicles (Fig. 10).

Mallory's trichrome-stained sections showed excessive amount of collagen fibers separating the gland lobules and also in between the follicles (Fig. 11). Weak PAS reaction appeared in the basal lamina of these follicles while colloid exhibited moderate PAS reaction in most follicles (Fig. 12). Concerning activated caspase-3 immunoreaction, strong positive reaction appeared in the nuclei and/or the cytoplasm of many follicular cells (Fig. 13).

In avocado and chlorpyrifos-treated group, the concomitant administration of both substances results in preserved histological architecture of the gland. Most of the follicles appeared with their normal cuboidal epithelial lining and filled with homogenous acidophilic colloid.
However, few follicles with vacuolated or no colloid were observed. In addition, focal areas with disrupted follicular epithelium and disrupted basal lamina were seen. Moreover, exfoliated cells and/or macrophages appeared in the lumen of these follicles. Dilated congested blood capillaries appeared also in some sections (Figs. 14, 15, 16).

Moreover, Mallory's trichrome-stained sections showed few collagen fibers separating the gland lobules and also inbetween the follicles (Fig. 17).

In PAS stained sections, variable degrees of the reaction appeared in the colloid while the follicular basal lamina showed moderate reaction (Fig. 18).

Moderate positive caspase-3 immunoreactivity was also observed in the nuclei and/or the cytoplasm of few follicular cells (Fig. 19).

\section{Morphometric and statistical results (Table 1)}

The mean height of the follicular epithelium in the chlorpyrifos-treated group (Group III) was significantly decreased (97.21 \pm 1.99$)$ compared to the control $(115.63 \pm 1.55)$, while avocado and chlorpyrifos-treated group (Group IV) showed a non-significant decrease $(114.30 \pm 1.30)$ compared to the control.

The mean area percentage of collagen fiber content in group III showed a significant increase $(6.742 \pm 0.809)$ compared to the control group (3.724 \pm 0.625$)$. While, group IV showed a non-significant increase $(4.678 \pm 0.925)$ compared to control group.

The mean area percentage of colloid in group III showed a significant decrease $(57.471 \pm 1.204)$ compared to the control group (62.226 \pm 0.969$)$. While, group IV showed a non-significant decrease $(60.979 \pm 0.529)$ compared to control group.

The mean color intensity of activated caspase-3 positive immuno-reactivity in group III showed a significant increase $(24.525 \pm 0.557)$ compared to the control group (13.171 \pm 0.671$)$, while group IV showed a non-significantincrease $(14.028 \pm 0.453)$ compared to control group.

Table 1: Showing morphometric analysis of the thyroid gland specimens in different groups.

\begin{tabular}{lcccc}
\hline \multicolumn{1}{c}{ Groups } & Group I & Group II & Group III & Group IV \\
\hline Parameters & $115.63 \pm 1.55$ & $115.64 \pm 1.28$ & $97.21 \pm 1.99 *$ & $114.30 \pm 1.30$ \\
Mean height of the follicular epithelium $(\mu \mathrm{m})$ & $3.724 \pm 0.625$ & $3.954 \pm 0.893$ & $6.742 \pm 0.809^{*}$ & $4.678 \pm 0.925$ \\
Mean area percentage of collagen & $62.226 \pm 0.969$ & $62.349 \pm 0.755$ & $57.471 \pm 1.204^{*}$ & $60.979 \pm 0.529$ \\
Mean area percentage of colloid & $13.171 \pm 0.671$ & $13.329 \pm 0.476$ & $24.525 \pm 0.557^{*}$ & $14.028 \pm 0.453$ \\
Mean color intensity of caspase-3 & &
\end{tabular}

Data are expressed as mean \pm standard deviation

$* P<0.05$ is significant versus control. 


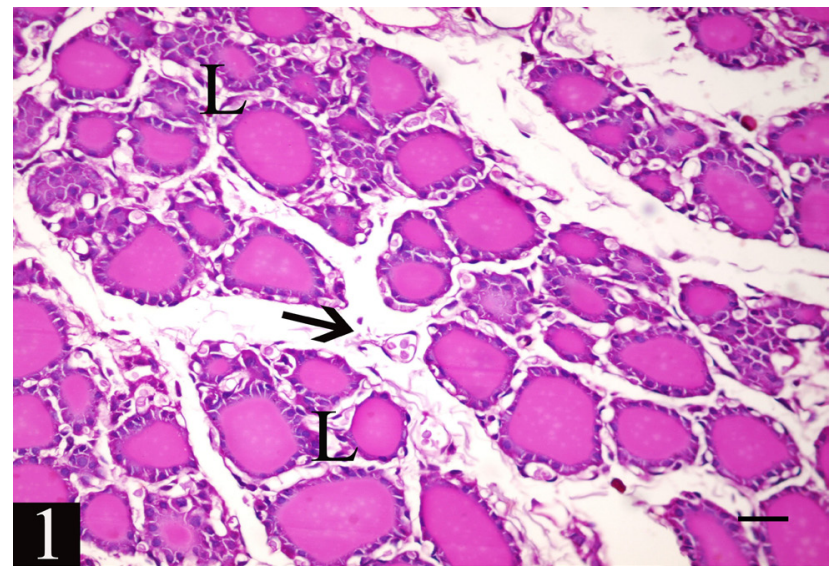

Fig. 1: A photomicrograph of thyroid gland section from control group showing numerous irregular lobules (L) separated by CT septa (arrow) containing blood vessels

$($ H\&E. X $400 ;$ Scale bar $=25 \mu \mathrm{m})$

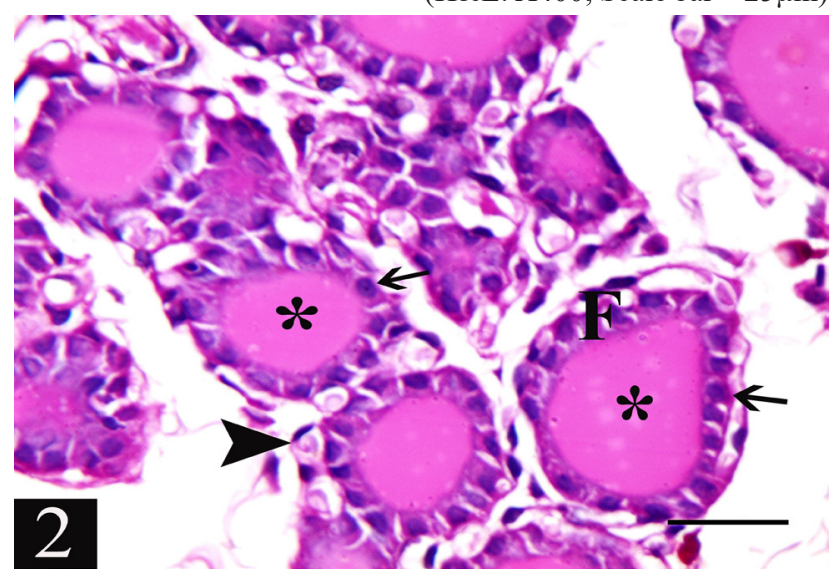

Fig. 2: A photomicrograph of thyroid gland section from control group showing thyroid lobule containing variable sized follicles (F) with capillary beds (arrow head) in between. The follicles appeared lined by single cuboidal epithelial cell layer having central and rounded pale nuclei (arrows). Notice the presence of homogenous acidophilic colloid in the lumen of the follicles $\left(^{*}\right)$.

$($ H\&E. X1000; Scale bar $=25 \mu \mathrm{m})$

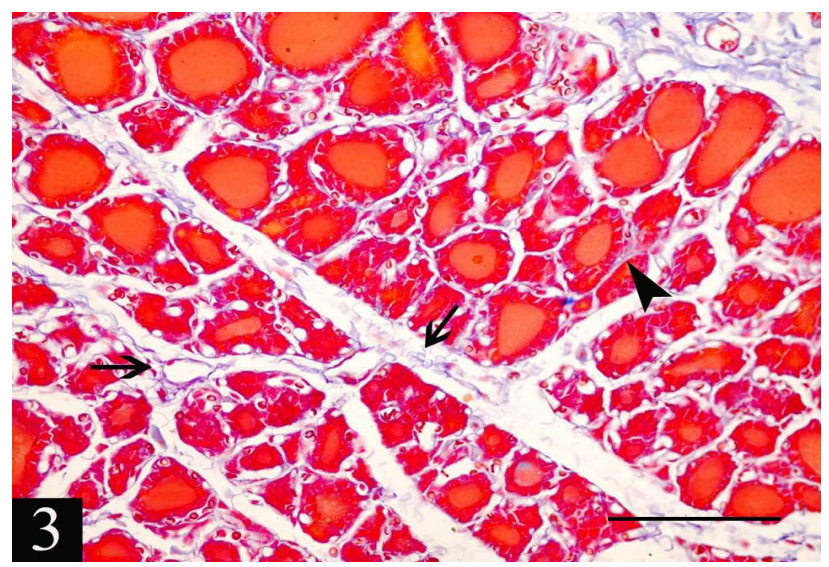

Fig. 3: A photomicrograph of thyroid gland section from control group showing thin collagen fibers (appeared blue) separating the gland lobules (arrows) and also in between the follicles (arrow head).

(Mallory's trichrome. X400; Scale bar $=25 \mu \mathrm{m}$ )

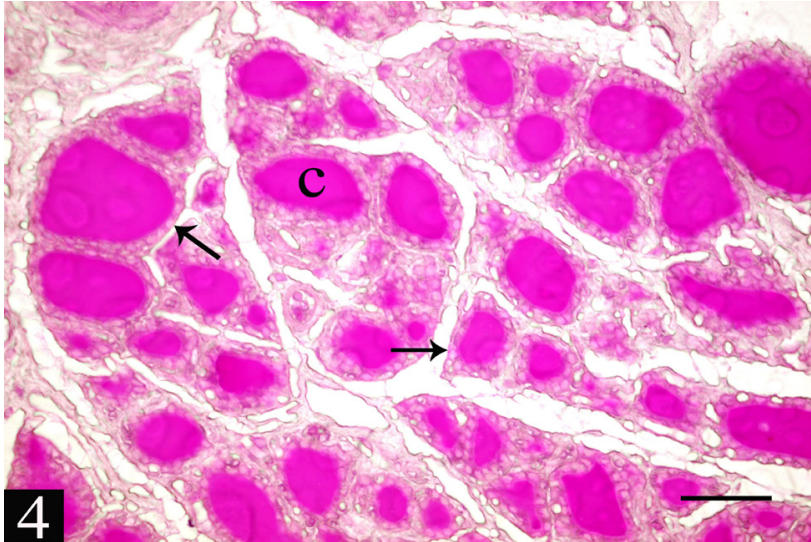

Fig. 4: A photomicrograph of thyroid gland section from control group showing the colloid of the follicles with strong PAS reaction $(\mathrm{C})$ and the basal lamina of the follicular epithelium with moderate reaction (arrows).

$($ PAS. X400; Scale bar $=50 \mu \mathrm{m})$

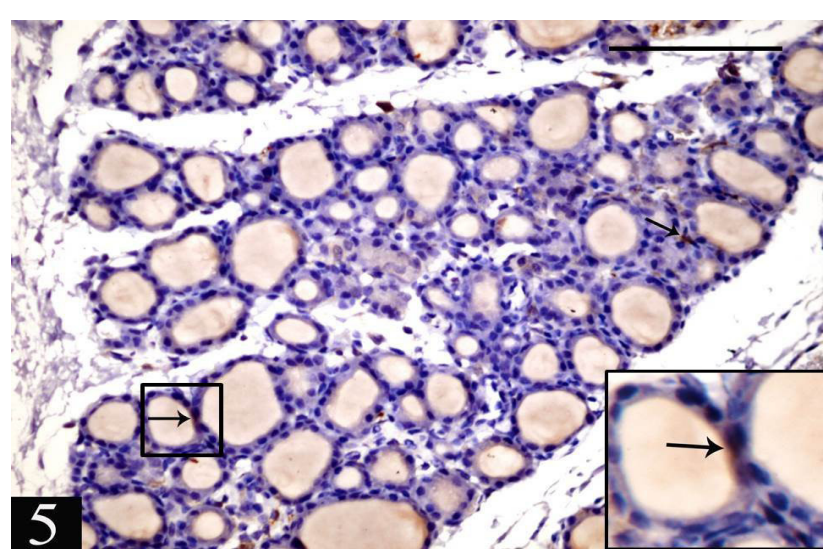

Fig. 5: Photomicrographs of thyroid gland sections from control group showing weak positive nuclear and/or cytoplasmic immunoreactivity (arrows) for caspase- 3 in few follicular cells. (Caspase-3 immunostaining, X400, Inset X1000; Scale bar $=$ $25 \mu \mathrm{m})$

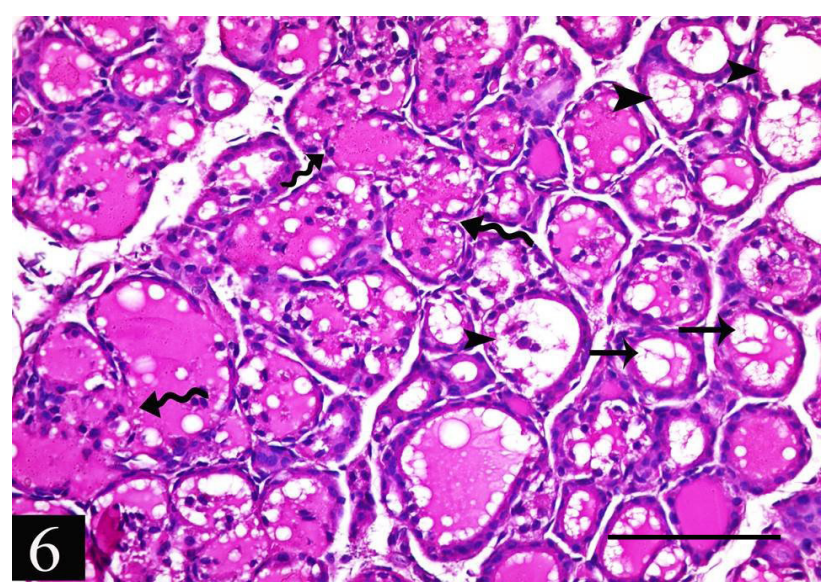

Fig. 6: A photomicrograph of thyroid gland section from chlorpyrifos-treated group showing some follicles with vacuolated colloid (arrows) and others with no colloid (arrow heads). Notice disruption of the follicular basal lamina with fusion of some follicles (wavy arrows).

$($ H\&E. X400; Scale bar $=25 \mu \mathrm{m})$ 


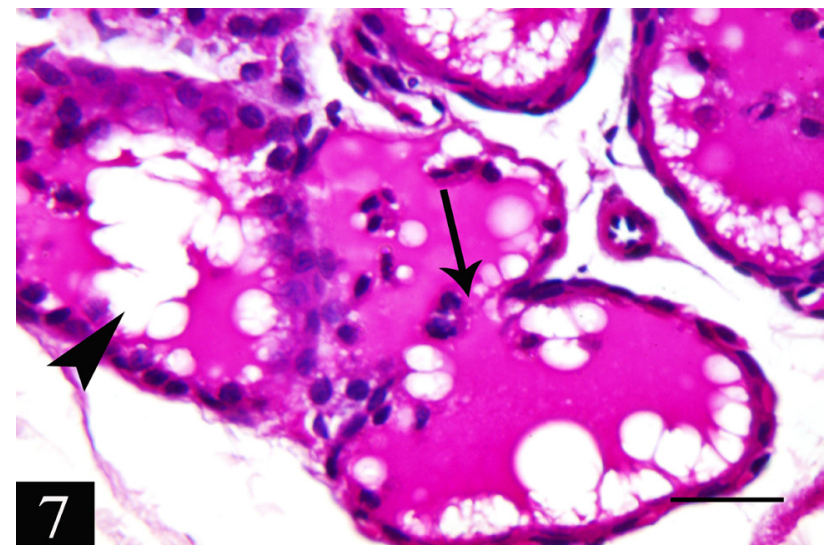

Fig. 7: A photomicrograph of thyroid gland section from chlorpyrifos treated group showing disruption of the follicular basal lamina with fusion of the follicles (arrow). These follicles are dilated with stagnant secretion and flattened nuclei. Notice follicles with vacuolated colloid (arrow head).

$(H \& E$. X1000; Scale bar $=25 \mu \mathrm{m})$

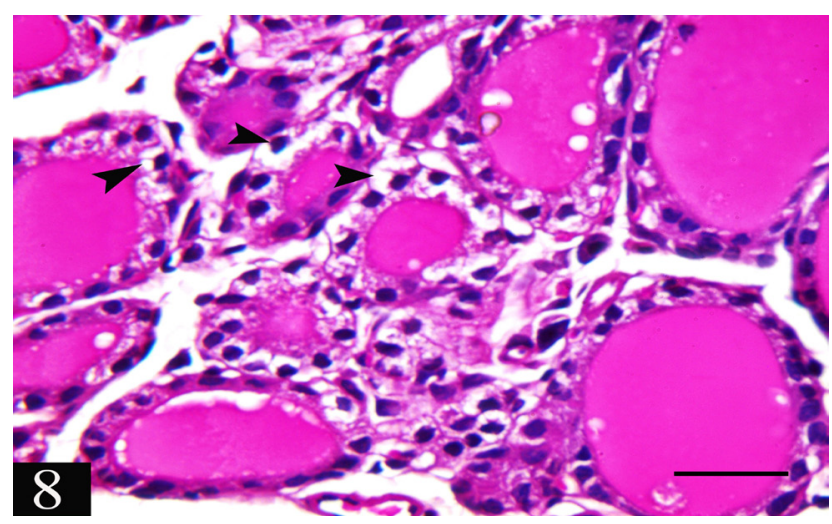

Fig. 8: A photomicrograph of thyroid gland section from chlorpyrifos-treated group showing follicular cells with cytoplasmic vacuoles and deeply stained nuclei (arrow heads).

$($ H\&E. X1000; Scale bar $=25 \mu \mathrm{m})$

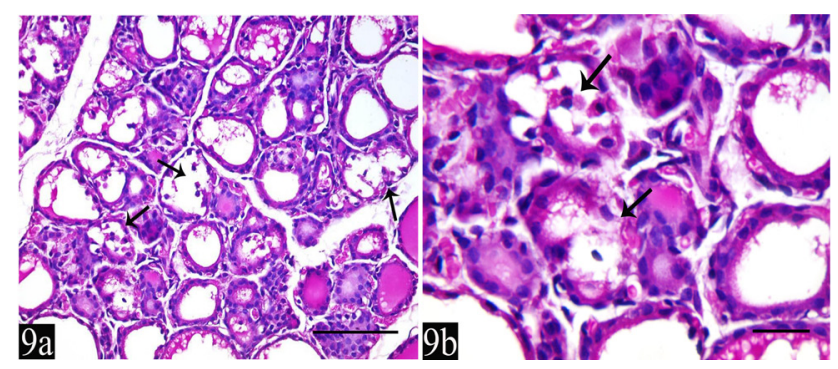

Fig. 9 (a, b): Photomicrographs of thyroid gland sections from chlorpyrifos-treated group showing degenerated follicles with exfoliated follicular cells in their lumens (arrows).

$($ H\&E. a X400, b X1000; Scale bar $=25 \mu \mathrm{m})$

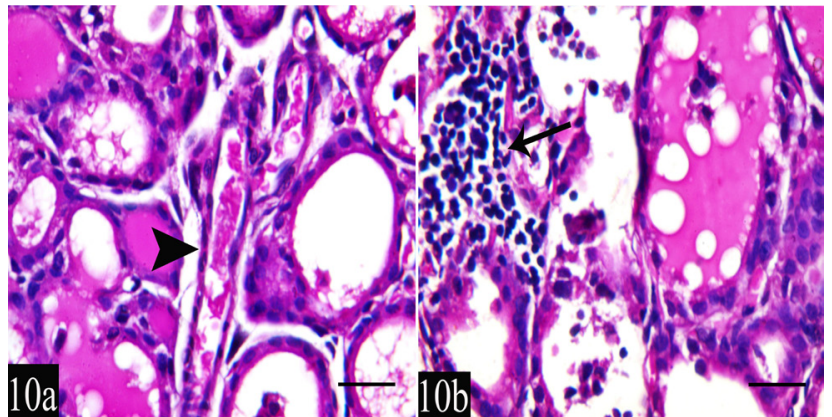

Fig. 10: Photomicrographs of thyroid gland sections from chlorpyrifos-treated group showing: (a) Dilated congested blood vessels (arrowhead). (b) Mononuclear cellular infiltration (arrow). $($ H\&E. a, b X 1000; Scale bar $=25 \mu \mathrm{m})$

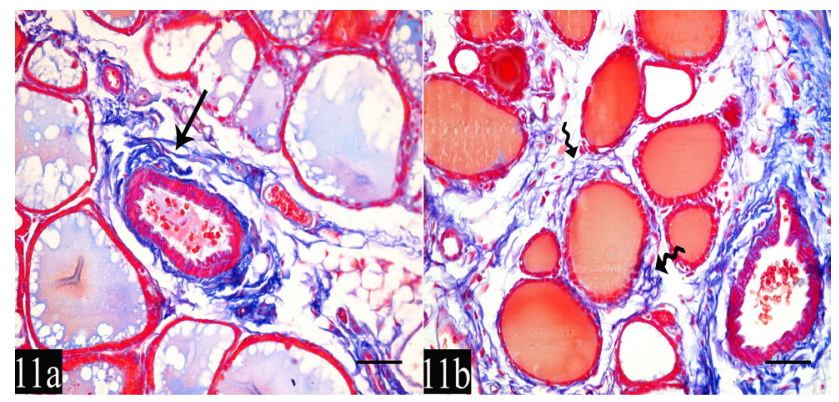

Fig. 11: Photomicrographs of thyroid gland sections from chlorpyrifos-treated group showing: (a) Excessive amount of collagen fibers separating the gland lobules (arrow). (b) Excessive amount of collagen fibers inbetween the follicles (wavy arrows). (Mallory's trichrome. a, b X400; Scale bar $=50 \mu \mathrm{m}$ )

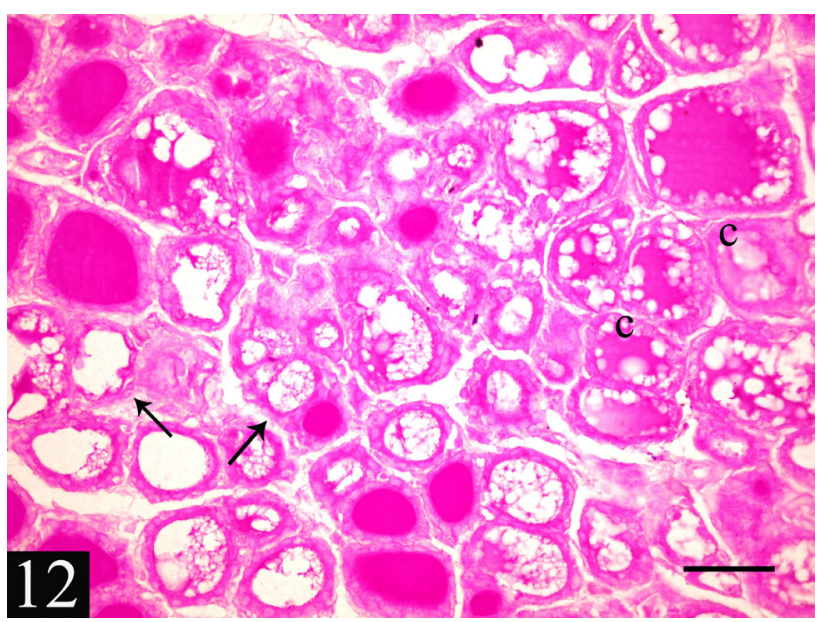

Fig. 12: A photomicrograph of thyroid gland section from chlorpyrifos-treated group showing the colloid of the follicles with moderate PAS reaction (C) and the basal lamina of the follicular epithelium with weak reaction (arrows).

$($ PAS X400; Scale bar $=50 \mu \mathrm{m})$ 


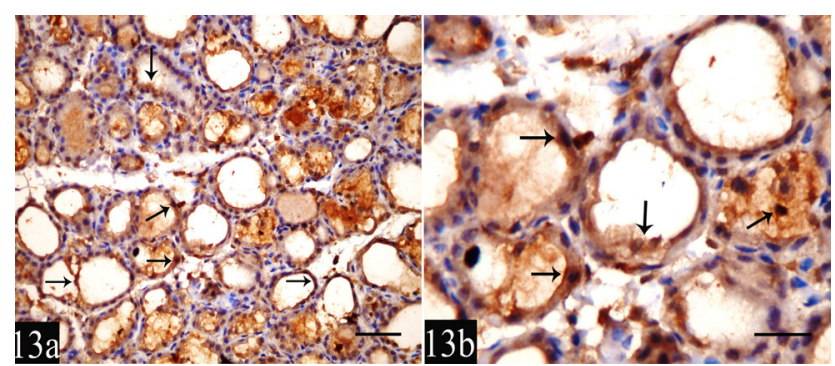

Fig. 13 (a, b): Photomicrographs of thyroid gland sections from chlorpyrifos-treated group showing strong positive nuclear and cytoplasmic immunoreactivity (arrows) for caspase-3 in many follicular cells.

(Caspase-3 immunostaining, a X400; Scale bar $=50 \mu \mathrm{m}, \mathrm{b}$ $\mathrm{X} 1000$; Scale bar $=25 \mu \mathrm{m})$

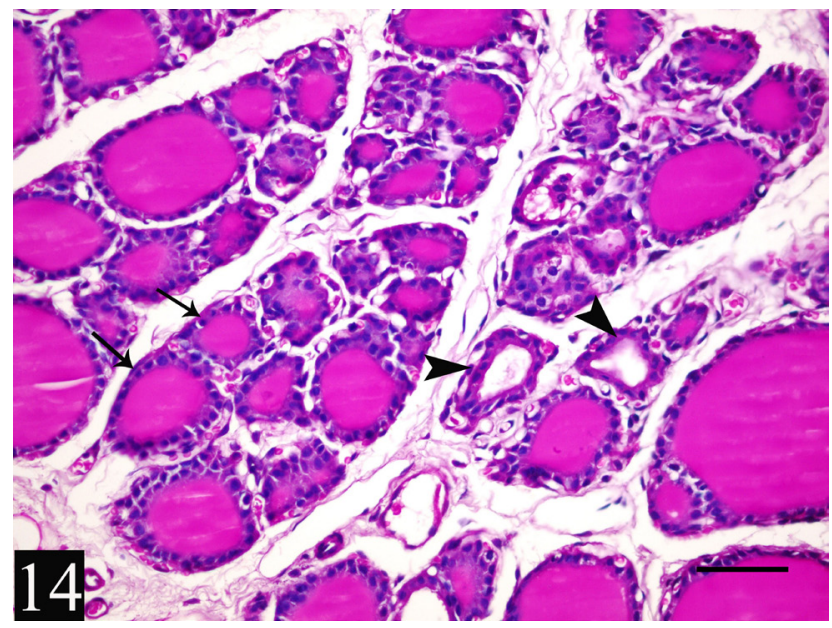

Fig. 14: A photomicrograph of thyroid gland section from avocado- and chlorpyrifos-treated group showing preservation of the normal architecture of the gland. Most of the follicles appeared with their simple cuboidal epithelial lining and filled with colloid (arrows). Notice the presence of few follicles with no colloid

$(\mathrm{H} \& \mathrm{E} . \mathrm{X} 400 ;$ Scale bar $=50 \mu \mathrm{m})$

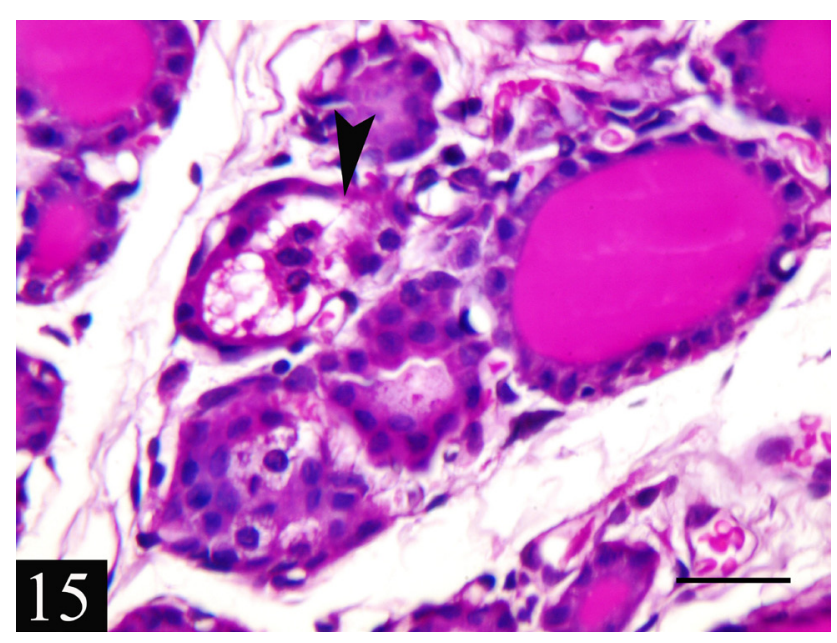

Fig. 14: A photomicrograph of cardiac muscles of group I showing no expression of caspase-3.

Group I Caspase-3 X400

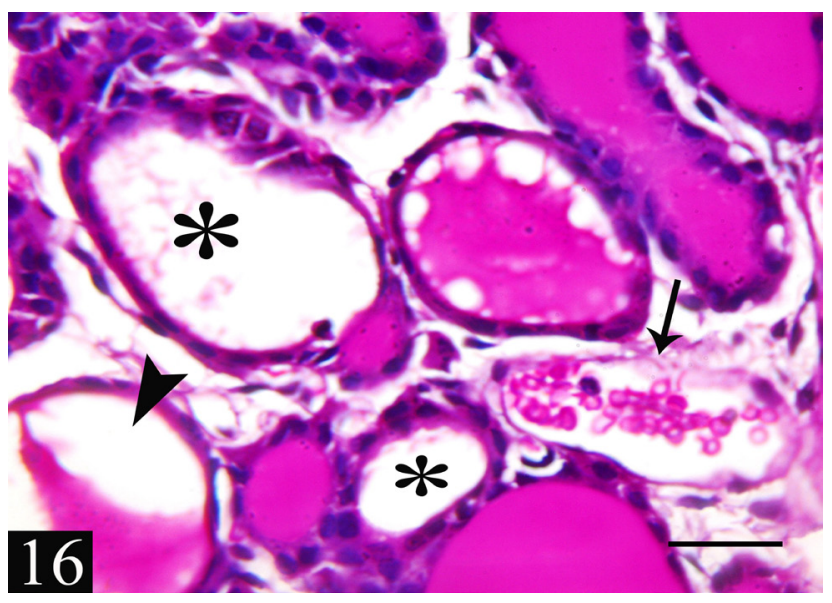

Fig. 16: A photomicrograph of thyroid gland section from avocado \& chlorpyrifos treated group showing few follicles with vacuolated (arrow head) or no colloid $(*)$. Notice the dilated congested blood vessel (arrow).

$(H \& E$. X1000; Scale bar $=25 \mu \mathrm{m})$

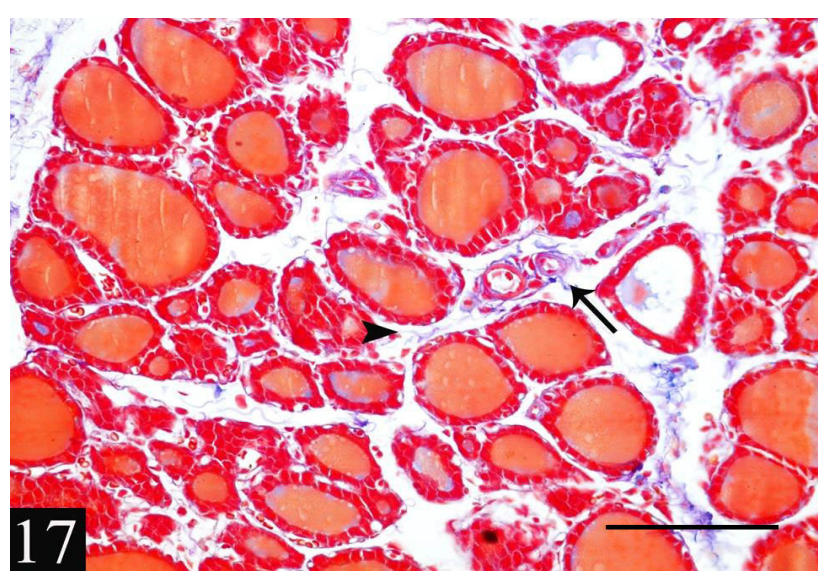

Fig. 17: A photomicrograph of thyroid gland section from avocado \& chlorpyrifos-treated group showing few collagen fibers separating the gland lobules (arrow) and also in between the follicles (arrow head).

(Mallory's trichrome. X400; Scale bar $=25 \mu \mathrm{m}$ )

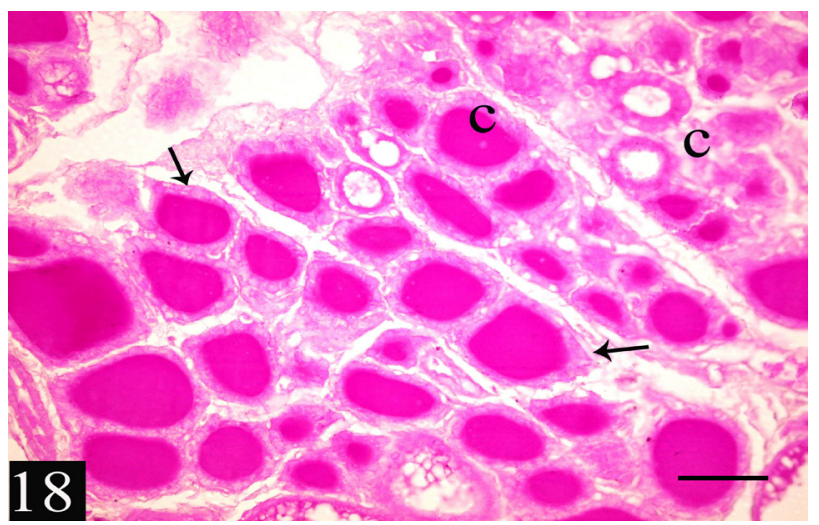

Fig. 18: A photomicrograph of thyroid gland section from avocado and chlorpyrifos-treated group showing the colloid of the follicles with variable PAS reaction (C) and the basal lamina of the follicular epithelium with moderate reaction (arrows).

$($ PAS. X400; Scale bar $=50 \mu \mathrm{m})$ 


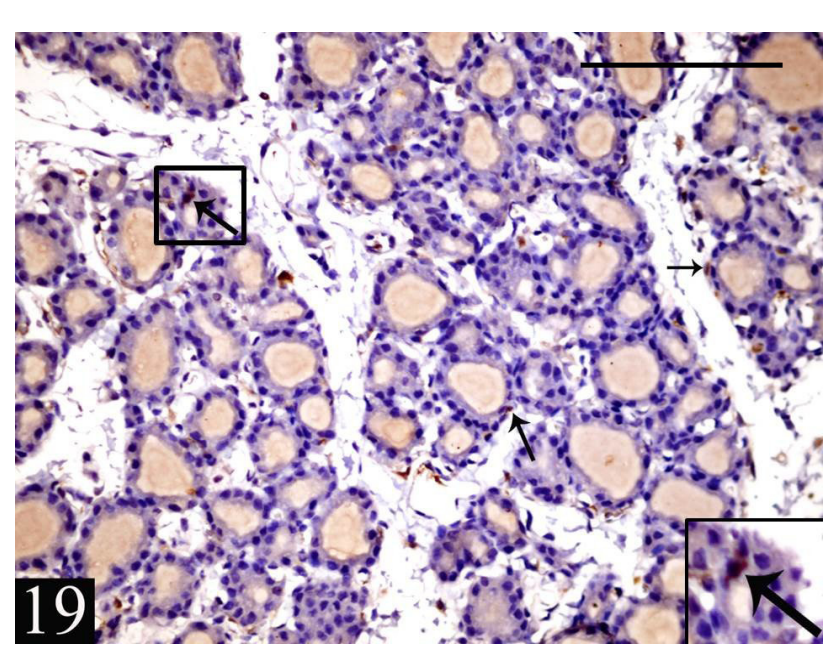

Fig. 19: A photomicrograph of thyroid gland section from avocado- and chlorpyrifos-treated group showing moderate positive nuclear and/or cytoplasmic immunoreactivity (arrows) for caspase-3 in few follicular cells.

(Caspase-3 immunostaining, X400, Inset X1000;

Scale bar $=25 \mu \mathrm{m})$

\section{DISCUSSION}

Thyroid hormones are responsible for many physiological processes in mammals. Chlorpyrifos is a well-known endocrine disrupter that is capable of inducing disturbance in the thyroid functions ${ }^{[2]}$. Therefore, the focus of our study was to assess the possible protective role of avocado pulp extract on chlorpyrifos-induced thyroid gland injury in adult male albino rats.

Our results denoted that chlorpyrifos administration to albino rats induced marked alterations in the thyroid gland structure. These appeared in the form of follicular cell degeneration, cellular infiltration, blood vessels congestion, increased deposition of collagen fibers within the gland, and decreased colloid content of the follicles. Moreover, significant decrease in the mean height of the follicular epithelium and significant increase in caspase-3 immuno-expression were also found.

In line with this study, some researchers assumed that chlorpyrifos induced degenerative changes in seminiferous tubules of the testis with reduced testosterone level ${ }^{[25]}$. Some investigators reported that chlorpyrifos affects the thyroid function leading to hypothyroidism and attributed this to follicular cell degeneration and apoptosis with subsequent reduced secretion ${ }^{[26,27,2]}$. Others attributed the inhibitory effect of chlorpyrifos on thyroid function to reduced iodine trapping and also to chlorpyrifos induced oxidative stress. The authors assumed that chlorpyrifos-induced oxidative stress was evident by increase in malondialdehyde (MDA) level (indicator for lipid peroxidation), enhanced reactive oxygen species (ROS) level, and decrease in reduced glutathione (GSH) level as well as impaired catalase and superoxide dismutase activity ${ }^{[13]}$. ROS interact with the target cell membrane leading to membrane damage with subsequent affection of cellular homeostasis. The oxidative damage affected the thyroid tissue inducing reduction of thyroid hormone levels ${ }^{[28]}$. Such effect had been proven in many organs of the experimental animals as brain, liver, kidney, and lung. Whereas, increased lipid-peroxidation and altered antioxidant mechanisms resulted in oxidative damage of these tissues ${ }^{[4,6-8]}$. Similar results were reported also in another in vitro study on the effect of chlopyrifos on human erythrocytes ${ }^{[29]}$.

The increased caspase- 3 immunoexpression in the follicular epithelial cells denoted apoptotic cell death induced by chlorpyrifos exposure attributed to oxidative damage, ROS production, and lipid peroxidation. Moreover, excess collagen fiber deposition in this study was also due to lipid peroxidation which stimulates the satellite cells to increase collagen synthesis also affected the vascular wall with subsequent dilatation and congestion of blood vessels ${ }^{[30,31]}$. Other researchers assumed that this hyperemia is an attempt for removal of the toxicant ${ }^{[32]}$. This study showed significant decrease in the height of the follicular epithelium and reduced area percentage of colloid as well as fusion of some follicles. This was in agreement with a previous research on the effect of sodium fluoride on the thyroid gland. The authors assumed that these changes are signs of gland degeneration and attributed the reduced follicular cell height to reduced activity of the follicular epithelial cells. Moreover, this denoted resting or unstimulated follicular epithelial cells as the cell height depends mainly on the functional condition of the gland $^{[33]}$.

Furthermore, after the insult, adhesion of the damaged cells to the basement membrane is reduced. Detachment of these damaged cells from basement membrane occurs with subsequent sloughing of the cells. Moreover, disturbed cell volume as well as ion homeostasis occur in the affected epithelial cells leading to changes in ion permeability and ATP depletion. This results in sodium influx, swelling and cell membrane rupture. So, this disturbed ion permeability may be a cause for cell death. Mononuclear cellular infiltration was also observed in this study and was attributed to hypersensitivity following toxic drug exposure ${ }^{[32]}$.

Our results demonstrated that the "avocado pulp extract" exerted a potent protective effect against thyroid injury induced by chlorpyrifos. This finding is supported by previous data which assumed that avocado extract protected the myocardium against oxidative stress injury and infiltration. Avocado was known to suppress the inflammatory response by decreasing the inflammatory genes expression. It could also preserve the cellular membranes integrity. Moreover, it had been assumed that avocado improves the enzymatic and nonenzymatic antioxidant defense status as increased catalase 
activity, vitamin $\mathrm{C}, \mathrm{A}$ and $\mathrm{E}$. It could also attenuate the lipid peroxide products as MDA due to its free radical scavenging action ${ }^{[18]}$.

So, avocado extract can protect the thyroid tissue from oxidative damage through the antioxidant activities of its bioactive compounds. Selenium, copper, zinc, B vitamins, tyrosine, iron and iodine are important components of avocado which play a vital role in improving thyroid function and decreasing the oxidative stress in the gland. Furthermore, these components are involved in thyroid hormone synthesis ${ }^{[16]}$. Besides, the avocado phytochemicals had selective inhibitory action on caspase-3 preventing apoptosis ${ }^{[34]}$.Noteworthy, avocado oil is the main constituent of avocado pulp extract and most of the fruit nutrients, especially mono-unsaturated fatty acids "e.g. oleic acid" are found in... Previous studies attributed the anti-inflammatory and the antioxidant effects of avocado to its oil, which decreases the activity of the pro-inflammatory cytokines as well asthe ROS generation by damaged mitochondria ${ }^{[35,36]}$.

\section{CONCLUSION}

Avocado pulp extract had a major protective role against chlorpyrifos induced thyroid gland injury in rats. Subsequently, it is a promising natural product that may be useful in the prevention of chlorpyrifos-induced toxicity.

\section{CONFLICT OF INTEREST}

There are no conflicts of interest.

\section{REFERENCES}

1. Chen S, Liu C, Peng C, Liu H, HuM, Zhong G (2012). Biodegradation of chlorpyrifos and its hydrolysis product 3,5,6-trichloro-2-pyridinol by a new fungal strain Cladosporium cladosporioides Hu-01. PLoS One 7:e47205.

2. Akande MG, Shittu M, Uchendu C, Yaqub LS (2016). Taurine ameliorated thyroid function in rats co-administered with chlorpyrifos and lead. Vet Res Commun 40:123-129.

3. Jett DA (2011). Neurotoxic pesticides and neurologic effects. Neurol Clin 29:667-677.

4. Tripathi S and Srivastav AK (2010). Liver Profile of Rats after Long-Term Ingestion of Different Doses of Chlorpyrifos. Pesticide Biochemistry and Physiology 97(1):60-65.

5. Achie K and Akpomiemie ML (2011). Ascorbic Acid Ameliorates Toxic Effects of Chlopyrifos on Testicular Functions of Albino Rats British Journal of Pharmacology and Toxicology 2(5): 262-269.
6. Heikal T M, Mossa A T H, Marei G I K, Abdel Rasoul M A (2012). Cyromazine and Chlorpyrifos Induced Renal Toxicity in Rats: The Ameliorating Effects of Green Tea Extract. Journal of Environmental \& Analytical Toxicology 2(5):1-7.

7. Singh S, Kaur S, Budhiraja RD (2013). Chlorpyrifos-induced oxidative stress in rat's brain and protective effect of grape seed extract. The Journal of Phytopharmacology 2(3): 26-33.

8. Hassani S, Sepand MR, Jafari A, Jaafari J, Rezaee R, Zeinali M, Tavakoli F, Razavi-Azarkhiavi K (2015). Protective effects of curcumin and vitamin E against chlorpyrifos-induced lung oxidative damage. Hum Exp Toxicol 34(6):668-76.

9. Lebov JF, Engel LS, Richardson D, Hogan SL, Hoppin JA, Sandler DP (2016). Pesticide use and risk of end-stage renal disease among licensed pesticide applicators in the Agricultural Health Study. Occup Environ Med 73:3-12.

10. Viswanath G, Chatterjee S, Dabral S, Nanguneri S R, Divya G, Roy P (2010). Anti-Androgenic Endocrine Disrupting Activities of Chlorpyrifos and Piperophos. The Journal of Steroid Biochemistry and Molecular Biology 120:22-9.

11. Gilbert ME, Rovet J, Chen Z, Koibuchi N (2012). Developmental thyroid hormone disruption: prevalence, environmental contaminants and neurodevelopmental consequences. Neurotoxicology 33:842-852.

12. Ambali SF, Orieji C, Abubakar WO, Shittu M, Kawu MU (2011). Ameliorative Effect of Vitamin $\mathrm{C}$ on Alterations in Thyroid Hormones Concentrations Induced by Subchronic Coadministration of Chlorpyrifos and Lead inWistar Rats Journal of Thyroid Research Volume 2011, Article ID 214924: 1-6.

13. Lamfon HA (2014). Effect of Selenium on Chlorpyrifos-Induced Thyroid Toxicity in Albino Rats. Research in Endocrinology Vol. 2014, Article ID 751500: 1-11.

14. Mansour SA and Mossa AH (2011). Adverse effects of exposure to low doses of chlorpyrifos in lactating rats. Toxicology and Industrial Health 27(3) 213-224.

15. Gouegni EF and Abubakar H (2013). Phytochemical, Toxicological, Biochemical and Haematological Studies on Avocado (Persea americana) in Experimental Animals. NIFOJ 31 (1): $64-69$. 
16. Hamouda AF, Sameeh MY, Randa M, Shrourou RM (2016). Effect of Avocado (Persea Americana), Cabbage (Brassica Oleracea) and Ginger (Zingiber Officinale) on Rat Liver and Thyroid Injuries Induced by CCl4 (Carbon Tetrachloride) Journal of Pharmacy and Pharmacology 4:108-118.

17. Octavio CZ, Cirilo NH, Ma AU, Guadalupe S, Patricia HJ, Dulce M (2014). Effect of Dietary Intake of Avocado Oil and Olive Oil on Biochemical Markers of Liver Function in Sucrose-Fed Rats. Publishing Corporation BioMed Research International 2014: 595479.

18. Emam MA and Hegazy MGA (2015). Cardioprotective effect of Persea Americana mill fruit extract in experimental myocardial infarction. World Journal of Pharmaceutical Research 4 (10): 2552-2567.

19. Nayak BS, Raju SS, Chalapathi Rao AV (2008). Wound healing activity of Persea americana (avocado) fruit: a preclinical study on rats. Journal of Wound Care 17(3): 123-126.

20. Paules MG, Zaher JF, Hafez EM, El-Tahawy NF (2013). Toxicological Effects Induced by Chlorpyrifos Administration on Thyroid and Suprarenal Glands in Adult Male Albino Rats. Ain Shams J Forensic Med Clin Toxicol 20: 99-105.

21. Gaertner DJ, Hallman TM, Hankenson FC, Batcherder MA (2008). Anesthesia and analgesia for laboratory rodents. Anesthesia and analgesia in laboratory animals. 2 nd edition. Academic press, San Diego, CA. Boston. 239-240.

22. Bancroft JD and Gamble M. 2008. Theory and practice of histological techniques. 6th edition, Elsevier health science. 126-127.

23. Kiernan JA (2000): Histological and histochemical methods: Theory and practice. 3rd ed. ButterworthHeinemann: Oxford. 320-90.

24. Ramos-Vara JA, Kiupel M, Baszler T, Bliven L, Brodersen B, Chelack B, West K, Czub S, Del Piero F, Dial S, Ehrhart EJ, Graham T, Manning L, Paulsen D, Valli VE (2008). Suggested guidelines for immunohistochemical techniques in veterinary diagnostic laboratories. J Vet Diagn Invest 20: 393-413.

25. Sai L, Li X, Liu Y, Guo Q, Xie L, Yu G, Bo C, Zhang Z, Li L (2014). Effects of chlorpyrifos on reproductive toxicology of male rats. Enviro Toxicol 29 (9):1083-8.
26. Jeong $\mathrm{SH}$, Kim BY, Kang $\mathrm{HG}, \mathrm{Ku} \mathrm{HO}$, Cho JH. (2006). Effect of chlorpyrifos-methyl on steroid and thyroid hormones in rat F0- and F1generations. Toxicology 220(2-3):189-202.

27. Goldner WS, Sandler DP, Yu F, Hoppin JA, Kamel F, Levan TD (2010). Pesticide use and thyroid disease among women in the agricultural health study. Am J Epidemiol 171(4):455- 464.

28. Gultekin F, Ozturk M, Akdogan M (2000). The effect of organophosphate insecticide chlorpyrifos-ethyl on lipid peroxidation and antioxidant enzymes (in-vitro). Archives of Toxicology, 74(9): 533-538.

29. Deeba F, Raza I, Muhammad N, Raham H, Rehman Z, Azizulla A, Khattak B, Ulla F, Daud MK (2017). Chlopyrifos and lambda cyhalothrininduced oxidative stress in human erythrocytes: In vitro study. Toxicology and Industrial Health 33 (4): 297-307.

30. Yu F, Wang Z, Ju B, Wang Y, Wang J, Bai D (2008): Apoptotic effect of organophosphorus insecticide chlorpyrifos on mouse retina in vivo via oxidative stress and protection of combination of vitamins $\mathrm{C}$ and E. Exp Toxicol Pathol 59(6): 415-423.

31. Shady AM and Noor El-Deen FI (2013). Effect of chlorpyrifos on thyroid gland of adult male albino rats.Egypt J Histol 33(3): 441-450.

32. Rekha, Raina S, Hamid S (2013). Histopathological effects of pesticide-cholopyrifos on kidney in albino rats. Int J Res Med Sci. 1(4): 465-475.

33. Patil VV and Dhurvey VT (2015). Exposure to sodium fluoride affects thyroid follicular cells in albino rats. International Journal of Plant, Animal and Environmental science 5(1): 56-61.

34. Hamouda AF (2015). Study on the Effect of Avocado on Apoptosis, Oxidative Stress and Injuries Induced by Diethyl Nitrosamine in Rat Liver. Journal of Pharmacy and Pharmacology 3: 243-252.

35. Ranade SS and Thiagarajan P (2015). A review on Persea Americana Mill. (Avocado)- its fruit and oil. Int J PharmTech Res 8(6): 72-77.

36. Duarte PF, Chaves MA, Borges CD, Mendonca CRB (2016). Avocado: characteristics, health benefits and uses. Ciencia Rural 46(4)abr: 747-754. 


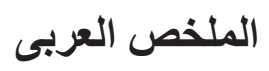

تأثثر مستخلص لب الأفوكادو على تلف الغدة الدرقية الناجم عن الكلوبيريفوس فى الجرذان : دراسة هستولوجية وقياسية شكلية

أميرة عدلى كساب1 ، منى الأعصر2

1قسم الهوتولوجيا، كلية الطب، 2قسم العقاقير، كلية الصيدلة ، جامعة طنطا ، طنطا ، مصر

المقدمة:: كلوربيريفوس هو مبيد حشرى يستخدم بانتشار فى مجال الزر اعة.و هو معروف بتأثثر اتة السامة على صحة الانسان.

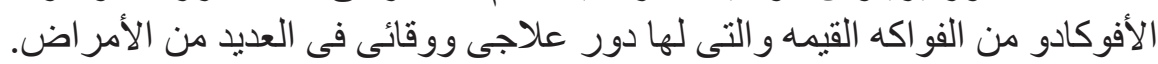

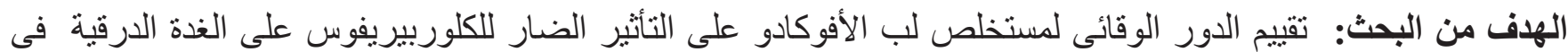
الجرذان. مواد وطرق البحث: تم تقسيم أربعين من ذكور الفئران البيضاء البالغة إلى أربع مجموعات متساوية. المجموعة الضابطة،

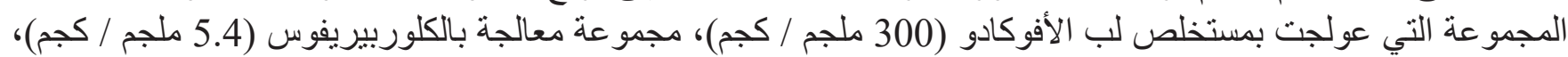
و المجمو عة التي عولجت بكلاهما. تم اعطاء الجرذان هذه الجر عات بالفم بو ميا لمدة 4 أسابيع متتالية. وقد تم تجهيز عينات الكات الغدة

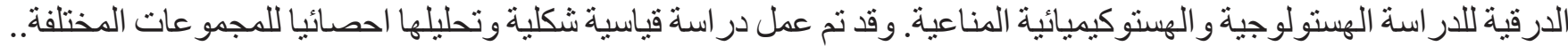

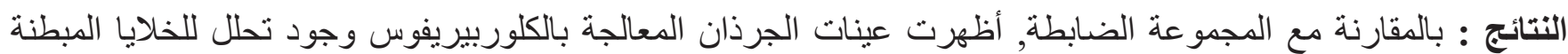

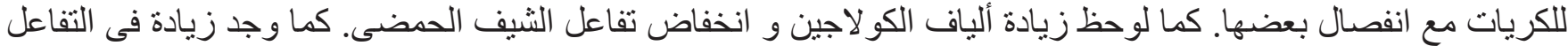

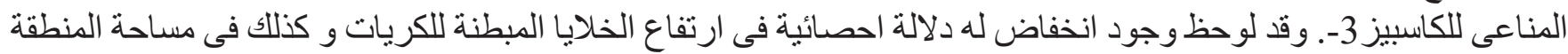
الغرو انية. و على النقيض فقد وجدت الإت تغير ات طفيفة للمجمو عة التى عولجت بكلا من الأفوكادو و الكلوربيريفوس.

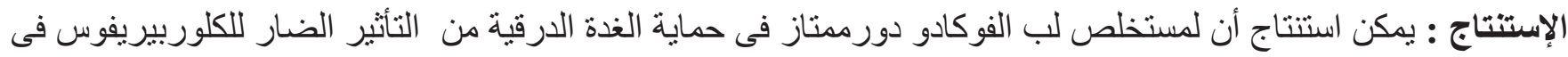
الجرذان. 